\title{
Letter \\ Are triple-negative tumours and basal-like breast cancer synonymous? Authors' response
}

\author{
Bas Kreike ${ }^{1,2}$ and Marc J van de Vijver ${ }^{3}$
}

\begin{abstract}
1'Division of Radiation Oncology, The Netherlands Cancer Institute, Plesmanlaan 121, 1066 CX Amsterdam, The Netherlands 2Division of Experimental Therapy, The Netherlands Cancer Institute, Plesmanlaan 121, 1066 CX Amsterdam, The Netherlands ${ }^{3}$ Division of Diagnostic Oncology, The Netherlands Cancer Institute, Plesmanlaan 121, 1066 CX Amsterdam, The Netherlands
\end{abstract}

Corresponding author: Marc J van de Vijver, m.vd.vijver@nki.nl

Published: 17 December 2007

This article is online at http://breast-cancer-research.com/content/9/6/405 (c) 2007 BioMed Central Ltd
Breast Cancer Research 2007, 9:405 (doi:10.1186/bcr1832)

See related letter by Rakha et al., http://breast-cancer-research.com/content/9/6/404, and related research article by Kreike et al., http://breast-cancer-research.com/content/9/5/R65

We read with interest the issues raised by Rakha and colleagues [1] in their response to our recent research article [2], and we are pleased to address them. An important conclusion from our research article is that triple-negative breast cancer can be equated to basal-like breast cancer. In their letter, Rakha and colleagues [1] state that equating triple-negative phenotype (TNP) tumours with basal-like breast cancer is misleading and is not supported by the data we have presented.

It is important to realize that, as we have also pointed out in our article [2], the basal-like breast cancer subtype was initially defined based on the gene expression pattern of the so-called 'intrinsic gene list' in only six breast tumours [3]. Since this initial report, the intrinsic gene list that is used to identify basallike breast tumours has been updated multiple times [3-5]. This shows that a gene-expression-based definition of basallike breast cancer has its limitations.

There are two reasons for Rakha and colleagues [1] to dispute our results. First, there are nine triple-negative tumours that have a gene expression pattern that is not strongly correlated to the basal-like centroid. However, when we do not set the threshold for the correlation coefficient to the molecular subtype centroids at 0.1 , but simply look at the closest centroid, all our unclassifiable samples will be allocated to the basal-like subtype. This leaves only the four samples that are allocated to the normal epithelial-like subtype. This is a problematic group, as it was originally defined on the basis of samples that did not contain tumour cells after neoadjuvant chemotherapy treatment and there are many similarities between this subtype and the basal-like subtype [3].

Second, Rakha and colleagues [1] state that '18.6\% of nonTNP cancers cluster together with TNP cancers in the "basal- like" cluster'. This argument is based on an incorrect understanding of our findings. These $18.6 \%$ are not part of a series of tumours that were all negative for a TNP, but $18.6 \%$ of a series of tumours not selected for TNP. These tumours include both TNP and non-TNP samples. In Additional file 1 [2], it is shown that some of these tumours have the gene expression pattern of triple-negative tumours-these are in fact the TNP tumours from this unselected series of tumours. This lends even greater support to the notion that triplenegative tumours are synonymous with basal-like tumours.

We therefore stand by our results and believe that gene expression profiling studies have highlighted the importance of basal-like/TNP tumours but that simple immunohistochemistry is sufficient to classify these tumours.

\section{Competing interests}

The authors declare that they have no competing interests.

\section{References}

1. Rakha EA, Tan DSP, Foulkes WD, Ellis IO, Tutt A, Nielsen TO, Reis-Filho JS: Are triple-negative tumours and basal-like breast cancer synonymous? Breast Cancer Res 2007, 9:404.

2. Kreike B, van Kouwenhove M, Horlings $H$, Weigelt $B$, Peterse $H$ Bartelink $\mathrm{H}$, van de Vijver MJ: Gene expression profiling and histopathological characterization of triple negative/basallike breast carcinomas. Breast Cancer Res 2007, 9:R65.

3. Perou CM, Sørlie T, Eisen MB, van de Rijn M, Jeffrey SS, Rees CA, Pollack JR, Ross DT, Johnsen H, Akslen LA, et al.: Molecular portraits of human breast tumours. Nature 2000, 406:747-752.

4. Hu Z, Fan C, Oh DS, Marron JS, He X, Qaqish BF, Livasy C, Carey LA, Reynolds E, Dressler L, et al.: The molecular portraits of breast tumors are conserved across microarray platforms. BMC Genomics 2006, 7:96.

5. Sørlie T, Tibshirani R, Parker J, Hastie T, Marron JS, Nobel A Deng S, Johnsen H, Pesich R, Geisler S, et al.: Repeated observation of breast tumor subtypes in independent gene expression data sets. Proc Natl Acad Sci U S A 2003, 100:8418-8423. 